\title{
ハムストリングスに焦点を当てたストレッチと 筋膜リリースの効果と比較検証
}

\author{
Effectiveness and Comparative Validation of Static Stretch and \\ Myofascial Release for the Hamstrings
}

$\begin{array}{llll}\text { 片山 } & \text { 慎吾 }^{1)} & \text { 竹重 } \text { 絢介 }^{1)} & \text { 佐伯 } \text { 美鈴 }^{1)} \\ \text { 人見 } & \text { 里絵 }^{2} & \text { 古谷 祥宏 } & \\ & \text { 是 }\end{array}$

Shingo KATAYAMA, RPT ${ }^{1)}$, Kensuke TAKESHIGE, RPT ${ }^{1)}$, Misuzu SAIKI, RPT ${ }^{1)}$, Yoshiniro FURUTANI, RST ${ }^{1)}$, RIE HITOMI, RPT ${ }^{2)}$, YUSUKE HOSHI, RPT ${ }^{3)}$, TAICHI HITOMI, OTR, MS ${ }^{4)}$

1) Department of Rehabilitation, Tokorozawa Rehabilitation Hospital: 1016 Nakatomi, Tokorozawa-shi, Saitama 359-0002, Japan TEL+81 429-43-1771 E-mail: shingo19820914@gmail.com

${ }^{2)}$ Rolf Release

${ }^{3)}$ Department of Rehabilitation, Sukagawa Hospital

4) Department of Occupational Therapy, Faculty of Health Science Technology, Bunkyo Gakuin University

Rigakuryoho Kagaku 35(5): 647-651, 2020. Submitted Mar. 25, 2020. Accepted May 22, 2020.

ABSTRACT: [Purpose] The purpose of this study was to compare the effect of static stretch and myofascial release. [Participants and Methods] Sixteen healthy adults were randomly assigned to two groups of eight participants each. Their mean age was $29.9 \pm 5.8$ years. The evaluation indices used were heel-to-floor distance at maximum elevation in the single leg raise (SLR), feeling of tension at maximum elevation (VAS), and a short-form self-report measure to assess relaxation effects (S-MARE). [Results] There were significant changes in SLR and VAS after the static stretch and myofascial release interventions, with increased SLR and decreased VAS. S-MARE showed a significant increase after the intervention only with the myofascial release. [Conclusion] Myofascial release was the most effective intervention examined in this study. However, it is difficult to determine the effectiveness of the interventions from only the findings of this study. It is necessary to select the appropriate interventions according to individuals' unique conditions.

Key words: stretch, myofascial release

要旨：〔目的〕本研究の目的は, ストレッチと筋膜リリースの効果を比較することである.〔対象と方法〕健常成人 16 名を 2 群に 8 名ずつ割り付けた。評価指標は, SLRにおける最大挙上時の踵から床までの距離, 最大挙上時のつっ ぱり感（VAS），心理的指標であるリラクセーション短縮版（S-MARE）を用いた。〔結果〕SLR と VAS はストレッチ， 筋膜リリースともに介入前後で有意な変化が認められ, SLRは増加, VAS は減少を示した. S-MAREは筋膜リリー スでのみ有意な変化が認められ，介入前後で増加を示した。〔結論〕本研究で検討した指標では，筋膜リリースが最 も効果的であった。しかしながら，これらの知見だけでは有効性を断定できず，状況に応じて適切な介入を選択する 必要があると考えられる。

キーワード：ストレッチ，筋膜リリース

\footnotetext{
1)所沢リハビリテーション病院リハビリテーション科：埼玉県所沢市中富 1016 ( ₹ 359-0002) TEL 0429-43-1771

2) Rolf Release

3) 須賀川病院 リハビリ部

4) 文京学院大学 保健医療技術学部 作業療法学科

受付日 2020 年 3 月 25 日 受理日 2020 年 5 月 22 日
} 


\section{I. はじめに}

ストレッチは障害予防，コンディショニング，パ フォーマンス改善の一環として, 関節可動域制限, 疼痛, 筋緊張, 血流の低下, 疲労などの改善を目的に実施され 有用性が先行研究によって示されてきた ${ }^{1-7)}$ ，その機序 は，筋・腱への持続的な伸張刺激によって，腱紡錘の活 動の興奮と $\alpha$ 線維の抑制が起こる過程であり, 該当筋の 活動を抑制する宜髄反射によって起こる。その方法は, 主に該当筋の起始と停止を一方向に引き離し筋活動を抑 制させ 1-7)，その多くは，ハムストリングスに焦点を当 てた報告がなされている1-3).

一方，筋膜リリースの報告は，ストレッチに比べ少な いものの, その重要性について徐々に注目されるように なってきている ${ }^{8-11)}$. 筋膜リリースの機序は, 徒手によ る物理的接触を介して様々な方向に圧刺激を加え, 固有 受容器・自由神経終末の発火を促し, 筋膜機能異常の改 善や，筋膜のねじれを整える効果がある ${ }^{8)}$. 筋膜機能異 常に至る原因は, 外傷, 廃用, 循環不全, 運動不足, 反 復運動，長期にわたる不良姿勢等が挙げられている ${ }^{9)}$. 基礎研究においては, 筋膜リリースの効果指標として, 主に心拍などの自律神経系を用いた心理的なリラクセー ション効果が報告されている12).

このように，両者の良好な成績が報告されているもの の, これらの比較検証を試みた研究は確認されなかっ た。また，最近になって身体とこころが同調することに よる健康的効果の報告が挙げられている ${ }^{13)}$. しかしな がら, これらの研究においては身体的側面と心理的側面 より検討された報告は見当たらなかった。本研究では健 康的効果を検証するにあたり，身体的・心理的側面にお ける指標を導入し, 健常成人者を対象とする基礎的研究 を試みた。

そこで本研究のアウトカム指標は, 次のように検討し た。対象部位はストレッチの先行研究で多く取り上げら れているハムストリングスに注目し, 下肢伸展挙上 (straight leg raising : 以下, SLR) と, 心理的指標として, リラクセーション評価尺度短縮版（Short-form Selfreport Measure to Assess Relaxation Effects : 以下, S-MARE）を選択した。これは，質問紙法の一つである ものの, 生理指標を用いた基準関連妥当性が検証されて いる14)。また，SLRの角度による客観的指標だけでなく 対象者の主観的指標も考察していくうえで重要な指標に なる ${ }^{15)}$ ，そこで我々は，主観的指標として SLR 時に起 こる対象部位のつっぱり感（Visual Analogue Scale：以 下，VAS）を加えた。

以上のことから, 本研究のアウトカム指標は, SLR, VAS, S-MAREの 3 つの指標を用いた。 これらの指標 から，ストレッチ，筋膜リリースの比較検証を実施する ことで，それぞれの特性が明らかとなり，今後の理学療
法アプローチにおける新たな発展の一助になると考えら れた。

\section{II. 対象と方法}

\section{1. 対象}

本研究は所沢リハビリテーション病院倫理委員会の承 認（承認日 2018 年 10 月 22 日）を得たのち, 研究者の 知人を中心に, 本研究の概要と倫理について記載した書 類を用い，機縁法による募集をかけた。賛同の得られた 実験参加者は，基礎疾患や服薬などによる影響を有しな い健常成人の男女 16 名, 年齢は $29.9 \pm 5.8$ 歳（平均 \pm 標準偏差）であった。そのうちの実験参加者をストレッ 于群 8 名, 筋膜リリース群 8 名に無作為に分けた.

\section{2. 方法}

本研究は評価・介入ともに右側で統一し, 施術者は被 検者と同性とした。検査者はSLR 測定時に 3 人, VAS は 1 人で実施した. SLR, VAS はベッド上で, S-MARE は座位による机上での回答としたＳSLR 検査者と方法 は，(1)骨盤の回旋や挙上を防止する者，(2)他動的に抵抗 を感じるまでSLR 操作をする者, (3)踵と床の距離をメ ジャーで測定する者, とした。（2)のSLR 検査者は，経 験年数 12 年目のセラピストとした。なお，(1)骨盤の動 きを防止する者と(2) SLR を実施する者とで互いに確認 し合いながら行った。

VAS はこの際の下肢のつっぱり感を評価用紙に記入 する方法で解答を求めた。評価用紙は, 線の左側につっ ぱりなし, 線の右側につっぱりありと, $10 \mathrm{~cm}$ の横線で 記載したものとした。介入後の評価は, 初期評価時と同 じ条件でつっぱり感を評価用紙に記入を求めた。

S-MARE は心理的リラクセーション指標の一つ16)で あり, 生理的緊張, 身体的評価, 認知的緊張によって構 成された 45 項目の主観的なリラクセーション反応を評 価するために作られたものを基に，榊原ら 17) が実験参 加者への負担を考慮するために開発した 15 項目の質問 項目より構成されている. 得点が高いほど心理的リラク セーションの良好な状態を示す。実験の流れは図 1 に示 した通りであった。

また, 本研究で用いる SLR 操作の信頼性を事前に検 討した。その方法は，上記 SLR 測定と同じ条件で，同 一検査者による被験者 5 名で 3 回ずつ測定した.

ストレッチは先行研究 1-4,18-20) に基づき, 評価と同様 SLR 最大挙上位置で 30 秒間 1 セットを実施した。

筋膜リリースは次のような内容を基に検討した。狭義 の膜組織として, 浅筋膜, 深筋膜, 筋外膜, 筋周膜, 筋 内膜を指し 9), 広義での膜組織として, 筋膜, 腱, 勒帯, 脂肪, 胸膜, 心膜など内臓を包む膜など骨格筋と無関係 な部分の結合組織が含まれる ${ }^{8)}$ 。ここでは，狭義の膜組 
織に焦点を当て，腱，勒帯，脂肪など，骨格筋と接する 組織を筋膜とした。施術者は国際ストラクチュラル・イ ンテグレーション連盟（以下, IASI）公認ロルフプラ クティショナーから実技指導を計 32 時間受講した男女 1 名ずつ計 2 名が実施した. IASI 公認ロルフプラクティ ショナーは, IASIによりトレーニングを受けた者であ る ${ }^{21)}$. 今回の方法は, 1980 年代に米国の生化学者であっ たロルフ博士によって開発された，ストラクチュラルイ ンテグレーション（以下，SI） 22)の一部を参考にしたも のである。実際の手順は次のように実施した。被験者は 膝を立てた背臥位を開始肢位とした。施術者により被験 者の右股関節を他動的に屈曲し, 内・外側ハムストリン グスをそれぞれランドマークとして，施術者の手で被験 者の右大腿後面遠位から近位に向かって圧刺激を持続的 に加えていった。所要時間は概ね 20 秒から 30 秒であっ た（図 2).

以上の方法で SLR, VAS, S-MAREの得られたデー 夕は，1回の測定で得られたものとした．

統計解析は, 男女比, SLR 測定の検者内信頼係数, ストレッチと筋膜リリースの比較を対象とした。性別の 比較は， $\chi^{2}$ の独立検定を実施した。 SLR 測定の検者内 信頼性は, 級内相関係数（intraclass correlation coefficient：以下, ICC) (1,3) を実施した。次に, 得ら れたデータから, すべての条件間の差の分散が等しいこ とを仮定するために Mauchly の球面性検定を実施した。 各アウトカム指標である SLR, VAS, S-MAREを従属 変数, ストレッチと筋膜リリースの「介入種類」と, ス トレッチ群と筋膜リリース群それぞれの介入「前後」の 2つを従属変数として, ストレッチ群, 筋膜リリース群 の変化を比較するために，二元配置分散分析を施行し た。 また，主効果および交互作用が有意であった場合， Holm 法による多重比較の検定を実施した，有意水準は $5 \%$ とし，統計ソフトはHAD Ver 16.023)を用いた。

\section{III. 結 果}

男女比の検定として $\chi^{2}$ による独立検定を行った結果, 男性 10 名 $(62.5 \%)$ ，女性 6 名 (37.5\%) であり，有意 差を認めなかった，検者内信頼性の合計点の $\operatorname{ICC}(1,3)$ $=0.86,95 \%$ 信頼区間 $([0.54,0.98])$ で 0 を含んでお らず，高い信頼性が確認された。各 SLR, VAS, S-MAREの球面性の仮定を検証した結果, 有意となっ ていないことから，すべての条件間の差の分散が等しい ことが確認された (Mauchly's W=1.00). 各 SLR, VAS, S-MAREの平均值, 標準偏差および前後の変化 の結果は表 1 の通りになった。なお，すべての項目にお いて, 介入前のストレッチ群と筋膜リリース群との間に は有意差を認めなかった。

SLR では, 前後の主効果 $(\mathrm{F}(1,14)=50.2, \mathrm{p}<0.01)$

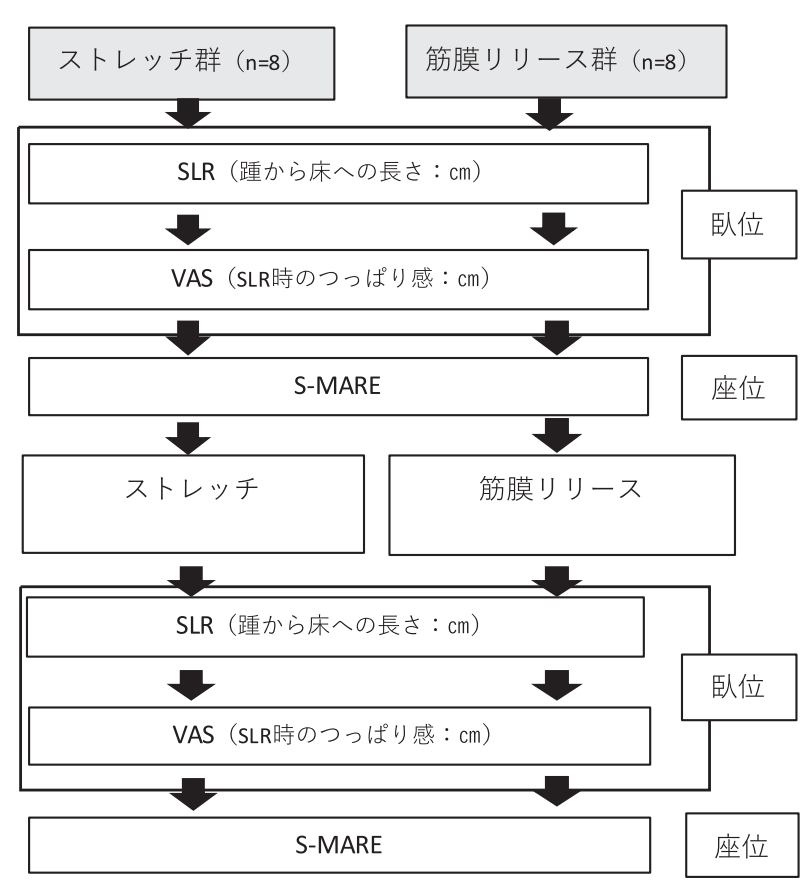

図1 実験の流れ

SLR：下肢伸展挙上, VAS：Visual Analogue Scale, S-MARE：リラクセーション評価尺度短縮版.

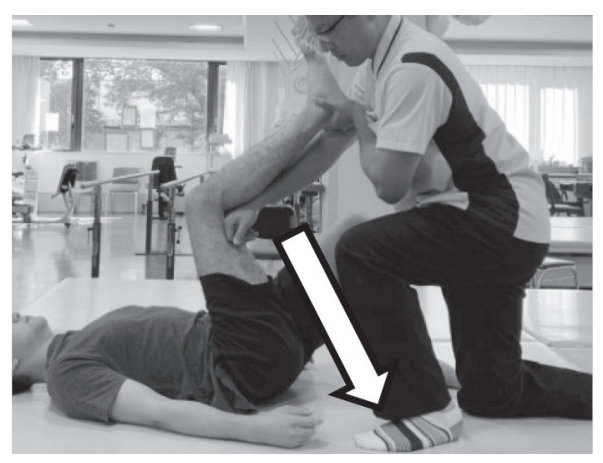

図2 ハムストリングスへのストローク方法

および交互作用 $(\mathrm{F}(1,14)=12.2, \mathrm{p}<0.01)$ に有意差を 認めた．次に Holm 法では，筋膜リリースの前 $(71.3 \pm$ $9.4 \mathrm{~cm})$ と後 $(78.9 \pm 8.8 \mathrm{~cm})$ に有意差を認め $(\mathrm{p}<0.01)$, ストレッチの前 $(73.8 \pm 7.9 \mathrm{~cm})$ と後 $(76.3 \pm 8.5 \mathrm{~cm})$ との間にも有意差を認めた $(\mathrm{p}<0.05)$. 筋膜リリース, ストレッチのいずれも実施することでSLR が増加する ことがわかった。

VAS では，介入種類 $(\mathrm{F}(1,14)=12.9, \mathrm{p}<0.01)$ お よび前後 $(\mathrm{F}(1,14)=35.6, \mathrm{p}<0.01)$ の主効果に有意差 を認めた。交互作用では有意差を認めなかった。次に Holm 法では, 筋膜リリースの前 $(4.1 \pm 1.5 \mathrm{~cm})$ と後 $(0.8 \pm 1.4 \mathrm{~cm})$ に有意差を認め $(\mathrm{p}<0.01)$, ストレッ チの前 $(5.6 \pm 2.0 \mathrm{~cm})$ と後 $(3.9 \pm 1.2 \mathrm{~cm})$ との間に 
表 1 各アウトカムの平均值および比較

\begin{tabular}{lccc}
\hline & SLR $(\mathrm{cm})$ & VAS $(\mathrm{cm})$ & S-MARE \\
\hline 前・筋膜リリース群 & $71.3 \pm 9.4^{*}$ & $4.1 \pm 1.5^{*}$ & $51.1 \pm 6.3^{*}$ \\
後・筋膜リリース群 & $78.9 \pm 8.8$ & $0.8 \pm 1.4^{\ddagger}$ & $58.9 \pm 7.3$ \\
前・ストレッチ群 & $73.8 \pm 7.9^{\dagger}$ & $5.6 \pm 2.0^{\dagger}$ & $53.1 \pm 4.1$ \\
後・ストレッチ群 & $76.3 \pm 8.5$ & $3.9 \pm 1.2$ & $53.0 \pm 8.7$ \\
\hline
\end{tabular}

平均值 \pm 標準偏差. SLR：下肢伸展挙上, VAS : Visual Analogue Scale, S-MARE：リラクセーション評価尺度短縮版. 多重比較 : Holm 法. * : p $<0.01$ (vs 後・筋膜リリース群), ${ }^{\dagger}: \mathrm{p}<0.05$ ( vs 後・ストレッチ群), 後・ストレッチ群).

も有意差を認めた $(\mathrm{p}<0.05)$. さらに筋膜リリースとス トレッチの比較に拈いては，ストレッチ $(3.9 \pm 1.2$ $\mathrm{cm})$ よりも筋膜リリース $(0.8 \pm 1.4 \mathrm{~cm})$ の方が有意に 減少した $(\mathrm{p}<0.01)$.

S-MAREでは, 前後の主効果 $(\mathrm{F}(1,14)=6.2, \mathrm{p}<$ $0.05)$ および，交互作用 $(\mathrm{F}(1,14)=6.6, \mathrm{p}<0.05)$ に 有意差を認めた。次に Holm 法では, 筋膜リリースの前 $(51.1 \pm 6.3)$ と後 $(58.9 \pm 7.3)$ に有意差を認めた $(\mathrm{p}<0.01)$. したがって，S-MAREに関しては，筋膜リ リースによって増加することがわかった。

\section{IV. 考 察}

本研究の結果より, ストレッチ群・筋膜リリース群と もに，先行研究を支持する内容となった，新たな知見と してSLR, VAS, S-MAREともに, ストレッチに比べ 筋膜リリース群の方が高い効果が得られたことであっ た. SLR, VASの結果およびストレッチ・筋膜リリー スの両者の機序の違いについて, 次のように考察した。

ストレッチは該当筋の筋活動を抑制する脊髄反射での 変化に集約されるのに対し, 筋膜リリースはテンセグリ ティ概念 ${ }^{24)}$ や動物実験 25,26) の報告から，ある一部位へ の介入から全体への波及が得られる効果が確認されてい る。さらに，ストレッチは筋腱移行部にアプローチが限 局するのに対して，筋膜リリースは接触した皮膚を介し， 筋，腱，細胞外基質などに作用すると考えられた ${ }^{27)}$. そのため, ストレッチは部分的なコンプライアンスの改 善は得られても, Stiffness の不均衡の改善や間質液の流 れの適正化は難しいと考えられた。一方, S-MAREでは, 筋膜リリース群のみ増加が認められた。この理由とし て, Minasny ${ }^{12)}$ は，筋膜と自律神経系は密接な関係性が ある「神経生物学の筋膜理論」を述べている。これは, 筋膜への圧力に反応し, 筋膜内の機械受容器が自律神経 系によって処理されることにより, 全体的な筋緊張の変 化や局所的な血管拡張および組織の粘性の変化をもたら すことが示されている. S-MAREは自律神経との基準 関連妥当性がなされていることから, 筋膜リリースに
よって, 副交感神経系が作用し，筋肉の緩みと穏やかな 心理的変化が得られたと考えられた。 また, Goyal ら 28) は，うつ病により，体性機能障害を呈することから，う つ病患者に対し，筋膜リリースを 6 週間導入した。その 結果，うつや生活の質の改善が認められた ${ }^{28)}$. 以上に より，身体的・心理的側面において，ストレッチよりも 筋膜リリースの方が高い効果を示す可能性が考えられ た。

しかしながら, 本研究には今後の課題が多数挙げられ る。一般的に, 筋膜リリースと呼ばれる方法はまだ統一 されておらず, その定義も不明確である ${ }^{8-11)}$. 本研究で 用いた方法は SI の一部を参考にしたに過ぎず，筋膜リ リースと呼ばれるすべての方法に精通したものではな い。また，アウトカム指標は非常に限られており，各々 の対象に適切な判断基準として取り入れていくためには 様々な視点からの検証が必要である。実際の筋膜構造の 変化に対する客観的な指標はないため, 超音波などの利 用を検討し，ストレッチとの比較を行う必要がある。本 研究の対象は, 健常成人を対象とした基礎的実験であっ た。整形外科的疾患や内科的疾患等, 様々な疾患を有す る方々を対象とした研究も検討している。今後において も，ストレッチ，筋膜リリースの有効性について更なる 議論を要するが, 目的に応じて適切に導入する知見が得 られれば, 臨床における理学療法プログラムの選択肢を 広げる可能性があると考えられる。

本報告は第 106 回理学療法科学学会学術大会にて報 告し，新たに修正，加筆を加えたものである。

利益相反 本研究に開示すべき利益相反はない.

\section{引用文献}

1) 谷澤 真, 飛永敬志, 伊藤俊一・他 : 短時間の静的ストレッ チングが柔軟性㧍よび筋出力に及ぼす影響. 理学療法学一 臨床・研究・教育, 2014, 21: 51-55.

2) 上野真志保, 廣瀬浩昭: ハムストリングスに対するスタティッ ク・ストレッチング中のSLR股関節角度変化. 関西理学療法, 2001, 1: 43-46. 
3) 木元裕介, 進藤伸一:ハムストリングスに対するスタティッ クストレッチが筋力と関節可動域に与える影響の時間的変 化. 秋田大学保健専攻要, 2011, 19: 27-33.

4) 土井眞里亜, 浦辺幸夫, 山中悠紀・他：静的ストレッチン グ後に生じる足関節可動域と筋力の経時的変化. 理学療法 科学, 2010, 25: 785-789.

5) Markovic G, Mikulic P: Neuro-musculoskeletal and performance adaptations to lower-extremity plyometric training. Sports Med, 2010, 40: 859-895.

6) Cormie P, McGuigan MR, Newton RU: Developing maximal neuromuscular power: Part 1-biological basis of maximal power production. Sports Med, 2011, 41: 17-38.

7) 市橋則明：ストレッチングのエビデンス. 理学療法学, 2014, 41: 531-534.

8) 鈴木茂樹, 浅賀亮哉, 銭田良博・他：エコーガイド下 Fasciaリリースの治療効果一Fasciaの痛みの原因と多職種 連携の必要性について一. 理学療法一臨床. 研究. 教育, 2019, 26: 3-7.

9) 竹井 仁: Myofascial Release (筋膜リリース). 理学療法科 学, 2001, 16: 103-107.

10) 勝又泰貴, 竹井 仁, 堀 拓郎 - 他: 筋再教育運動が筋膜 リリース後の筋筋膜の伸張性および筋力に与える影響. 理 学療法科学, 2016, 31: 99-106.

11) Robert $S$, Thomas $W$, Leon $C$, et al. : 人体の張力ネットワー ク膜・筋膜最新知見と治療アプローチ. 竹井 仁 (監訳), 医歯薬出版, 東京, 2017, pp89-94.

12) Minasny B: Understanding the process of fascial unwinding. Int J Ther Massage Bodywork, 2009, 2: 10-17.

13）山口 創：身体接触によるこころの癒し〜こころとからだ の不思議な関係〜. 全日本銊尒学会雑誌, 2014, 64: 132140.

14) 徳田完二：心理的リラクセーション尺度（ERS）の利点と基 準関連妥当性一大学生を対象とした調査から一, 立命館人 間科学研究, 2011, 23: 1-9.

15) Hitomi T, Yachi CT, Yamaguchi H: An experiment on the psychological and physiological effects of skin moisturization on lower legs-in expectation of application to nursing practice at hospitals. Behav Sci (Basel), 2018, 8: 91.
16) Crist DA, Rickard HC, Prentice-Dunn S, et al.: The relaxation inventory: self-report scales of relaxation training effects. J Pers Assess, 1989, 53: 716-726.

17) 榊原雅人, 寺本安隆, 谷 伊織 : リラクセーション評価尺 度短縮版の開発。心理学研究, 2014, 85: 284-293.

18) Behm DG, Chaouachi A: A review of the acute effects of static and dynamic stretching on performance. Eur J Appl Physiol, 2011, 111: 2633-2651.

19) Simic L, Sarabon N, Markovic G: Does pre-exercise static stretching inhibit maximal muscular performance? A metaanalytical review. Scand J Med Sci Sports, 2013, 23: 131-148.

20) 松岡 潤, 渡邊博史, 梨本智史・他：腓腹筋に対する傾斜 台を使用した静的ストレッチングの効果について。スポー ツ障害, 2013, 18: 10-13.

21) International Association of Structural Integrators: About AISI. https://www.theiasi.net/about-iasi (閲覧日 2020 年 4 月 25 日).

22) 日本ロルフ身体構造統合協会：日本ロルフ身体構造統合協 会について. https://rolfjapan.org/si(閲覧日2020年4月 25 日).

23) 清水裕士 : フリーの統計分析ソフト HAD機能の紹介と統計 学習・教育, 研究実践に扔ける利用方法の提案. メディア. 情報・コミユニケーション研究, 2016, 1: 59-73.

24) Schleip R: Fascial plasticity—a new neurobiological explanation: Part 1. J Bodyw Mov Ther, 2003, 7: 11-19.

25) 石井禎基, 崎田正博, 笹井宣昌・他：筋膜による筋間連結 の機能的役割一ウシガエル膝伸筋を用いた研究—. 理学療 法学, 2013, 40: 16-23.

26) Myers T : アナトミー・トレイン一徒手運動療法のための 筋筋膜経線. 板場英行, 石井慎一郎(監訳), 医学書院, 東京, 2017, pp48-56.

27) E Silva DC, de Andrade Alexandre DJ, Silva JG: Immediate effect of myofascial release on range of motion, pain and biceps and rectus femoris muscle activity after total knee replacement. J Bodyw Mov Ther, 2018, 22: 930-936.

28) Goyal M, Goyal K, Bathla M, et al.: efficacy of myofascial unwinding and myofascial release technique in a patient with somatic symptoms-a case report. Indian J Psychol Med, 2017, 39: 199-201. 